\title{
Un fragment de la Genèse en vers (fin XIII - début du XIV siècle). Edition du Ms. Brit. Libr. Harley 3775 par Julia C. Szirmai
}

\section{G. Matteo Roccati}

\section{(2) OpenEdition}

Journals

Édition électronique

URL : http://journals.openedition.org/studifrancesi/27227

DOI : 10.4000/studifrancesi.27227

ISSN : 2421-5856

Éditeur

Rosenberg \& Sellier

Édition imprimée

Date de publication : 31 décembre 2006

Pagination : 576

ISSN : 0039-2944

\section{Référence électronique}

G. Matteo Roccati, «Un fragment de la Genèse en vers (fin XIIIe - début du XIVe siècle). Edition du Ms. Brit. Libr. Harley 3775 par Julia C. Szirmai », Studi Francesi [En ligne], 150 (L | III) | 2006, mis en ligne le 30 novembre 2015, consulté le 08 novembre 2020. URL : http://journals.openedition.org/ studifrancesi/27227; DOI : https://doi.org/10.4000/studifrancesi.27227

Ce document a été généré automatiquement le 8 novembre 2020.

\section{c)}

Studi Francesi è distribuita con Licenza Creative Commons Attribuzione - Non commerciale - Non opere derivate 4.0 Internazionale. 


\title{
Un fragment de la Genèse en vers (fin XIII ${ }^{\mathrm{e}}$ - début du XIV siècle). Edition du Ms. Brit. Libr. Harley 3775 par Julia C. Szirmai
}

\author{
G. Matteo Roccati
}

\section{RÉFÉRENCE}

Un fragment de la Genèse en vers (fin XIII - début du XIV siècle). Edition du Ms. Brit. Libr. Harley 3775 par Julia C. Szirmai, Genève, Librairie Droz S.A. (“Textes littéraires français", 574), 2005, pp. 284.

1 Edition et étude d'un fragment en anglo-normand de 2148 vers, signalé (1888) puis partiellement édité (1907) par P. Meyer. Tronqué du début et de la fin, le récit commence par la dernière partie de la vie d'Abraham, relate l'histoire d'Isaac et Jacob et se termine par l'arrivée des frères de Joseph en Egypte (Gn 22-42). Si le point de départ est dans la Vulgate, le récit est basé sur l'Historia Scholastica de Pierre le Mangeur; lorsque le texte ne suit pas ces deux sources, il correspond pour une grande partie à Li Romanz de Dieu et de sa Mere d'Herman de Valenciennes, mais on trouve aussi des parentés avec d'autres traductions bibliques (notamment Macé de la Charité, Evrat, Jehan Malkaraume). Quelques détails sont tirés des Antiquités judaïques de Flavius Josèphe. Les moralisations et les allégories intégrées proviennent de l'Aurora de Pierre Riga, de la Glossa Ordinaria et des exégèses de Bède, Isidore et Raban. L'auteur insère également un conte extrait du Chastoiement d'un pere a son fils (traduction de la Disciplina clericalis).

2 La première partie du volume présente le manuscrit, la langue, la versification et le résumé du texte. Suivent l'examen des sources, conduit de manière détaillée (pp. 55-117), puis quelques considérations sur l'auteur, le public visé et la datation du 
poème. L'édition (pp. 129-191) est complétée par les notes (pp. 193-226), le glossaire (pp. 227-261), la bibliographie, l'index des noms propres et l'index général. 